\title{
Relevansi Pendidikan Humanis Paulo Freire Dengan Pendidikan Agama Kristen Jenjang Sekolah Menengah Atas
}

\author{
Juanda Manullang ${ }^{1 *}$, Renny Maria ${ }^{2}$, Agustinus Manullang ${ }^{3}$ \\ ${ }^{1}$ Institut Agama Kristen Negeri (IAKN) Manado, \\ ${ }^{2}$ Sekolah Tinggi Teologi (STT) Bethel Medan, \\ ${ }^{3}$ Sekolah Tinggi Teologi (STT) Siloam Medan \\ *juandamanullang@iakn-manado.ac.id
}

\begin{abstract}
This research is a descriptive qualitative research using the Library Research approach (library research). The data collection method used is the documentary method, which is to find and collect data on research variables in the form of books by Paulo Freire and the concept of Christian Religious Education. Then for data analysis, this study uses content analysis. The conclusions from the results of the research carried out are a) education should be a revolutionary vebicle to belp bumans achieve critical awareness and the ultimate goal of humanist education, namely to free bumans from the shackles of oppression so that they have human values back, b) there is a relevance of the humanist education concept of Paulo Freire with Christian Religious Education. in terms of the role of students, individual and community awareness, education based on social reality, and dialogue education towards a tolerant and democratic society.
\end{abstract}

Keywords: education; humanist education; paulo freire; christian religious education

\begin{abstract}
ABSTRAK
Penelitian ini merupakan penelitian kualitatif deskriptif dengan pendekatan Library Research (penelitian kepustakaan). Metode pengumpulan data yang dipakai adalah metode dokumenter, yaitu mencari dan mengumpulkan data mengenai variabel penelitian berupa buku-buku karangan Paulo Freire dan konsep Pendidikan Agama Kristen. Kemudian untuk analisis data, penelitian ini menggunakan analisis isi (Content Analysis). Kesimpulan dari hasil penelitian yang dilakukan adalah a) pendidikan semestinya menjadi kendaraan revolusioner untuk membantu manusia mencapai kesadaran kritis dan tujuan akhir pendidikan humanis yaitu membebaskan manusia dari belenggu penindasan sehingga memiliki kembali nilai kemanusiaan, b) terdapat relevansi konsep pendidikan humanis Paulo Freire dengan Pendidikan Agama Kristen dalam hal peran peserta didik, kesadaran individu dan masyarakat, pendidikan berbasis realitas sosial, serta pendidikan dialogis menuju masyarakat toleran dan demokratis.
\end{abstract}

Kata Kunci: pendidikan; pendidikan humanis; paulo freire; pendidikan agama kristen

Submitted May 15, 2021 | Revised Jun 08, 2021 | Accepted Jun 13, 2021

\section{Pendahuluan}

Pendidikan merupakan unsur penting dalam kehidupan manusia untuk membantu menyadari potensi yang dimiliki sebagai makhluk berpikir (Telaumbanua, 2020). Menurut George F. Kneller (Umiarso \& Zamroni, 2011), pendidikan dalam arti sempit adalah proses mentransformasi pengetahuan, nilai-nilai dan keterampilan dari generasi ke generasi, yang dilakukan oleh masyarakat melalui lembaga-lembaga pendidikan seperti sekolah, pendidikan tinggi atau lembaga-lembaga lainnya. Secara praktis pendidikan berfungsi sebagai sarana untuk mendapat pengetahuan, pelatih keterampilan dan pengasah otak, sebagai bekal untuk bertahan hidup dan dapat dilakukan di mana dan kapan saja agar tercapainya sebuah tujuan. Tujuan pendidikan yakni membentuk manusia agar mampu bersosialisasi dan berbudaya serta menyesuaikan diri dengan lingkungan agar berlangsungnya kehidupan baik secara pribadi maupun bermasyarakat (Suharyanto, 2015). Sehingga pendidikan dipandang sebagai investasi jangka panjang. Selain itu, pendidikan juga berfungsi melakukan penyadaran atas manusia untuk mampu mengenal, memahami dan mengerti realitas kehidupan sesungguhnya. Manusia sebagai subjek perubahan dituntut untuk kritis melihat realitas yang ada agar tetap sesuai dengan nilai-nilai kemanusiaan. Hal inilah menjadikan pendidikan mengemban nilai 
kemanusiaan untuk dapat memanusiakan kembali manusia dan digunakan sebagai sarana untuk mencapai pembebasan serta strategi untuk mencapai keadilan sosial. Pembebasan tersebut bermuara pada peningkatan daya kreatifitas berpikir yang lebih produktif (Idris, 2009).

Oleh sebab itu, Paulo Freire (Mansour Fakih, 2010) menawarkan suatu konsep pendidikan yang berorientasi pada proses pembebasan manusia. Baginya, manusia sejati adalah manusia yang kritis dan sadar akan realitas yang ada di sekelilingnya dan bertindak mengatasi realitas tersebut jika ia temui ketimpangan atau kesenjangan yang seharusnya tidak demikian. Untuk membangun kesadaran kritis tersebut dibutuhkan suatu perangkat untuk mendiagnosa realitas tersebut. Pendidikan menjadi perangkat untuk menghadapi realitas dalam membangun kesadaran kritis (Kristianto, 2021). Menurut Freire (Syaikhudin, 2012), tujuan utama dari pendidikan adalah membuka mata peserta didik guna menyadari realitas ketertindasannya untuk kemudian bertindak melakukan transformasi sosial. Selain kesadaran kritis, Paulo Freire dalam konsep pendidikan juga mengembangkan pendidikan dialogis, di mana diberikannya keleluasaan dan keterbukaan peserta didik untuk mengaktualisasikan diri dengan dibukanya ruang-ruang dialog yang partisipatif.

Berkaca pada konsep Paulo Freire di atas, amat menarik jika dikaitkan dengan konteks pendidikan Indonesia saat ini khususnya Pendidikan Agama Kristen. Dalam kehidupan berbangsa dan bernegara, Indonesia menghadapi berbagai permasalahan yang kompleks, seperti konflik yang sering kali diikuti dengan kekerasan, bahaya perpecahan atau disintegrasi bangsa, pelanggaran HAM, ketidakadilan sosial, pelecehan terhadap hukum, diskriminasi terhadap masyarakat marginal, kekerasan kepada perempuan dan anak-anak, reformasi dan demokratisasi yang disinyalir "jalan di tempat", serta kemiskinan yang semakin membuat terpuruknya kehidupan bangsa. Oleh karena itu, pendidikan di Indonesia sudah seharusnya menghadapkan peserta didik pada realitas permasalahan tersebut (Putra, 2020).

Menghadapi berbagai permasalahan tersebut, Pendidikan Agama Kristen (PAK) diperhadapkan pada pertanyaan yang penting dan mendesak, yaitu: bagaimana cara menghasilkan PAK yang mampu memperbarui penghayatan serta panggilan sebagai umat Kristen serta sekaligus memberikan sumbangan bagi kehidupan bersama sebagai satu bangsa (Wowor, 2021). Hal ini penting direnungkan karena umat Kristen Indonesia adalah bagian dari bangsa Indonesia yang turut serta membidani, melahirkan, dan mengukir sejarah serta patut proaktif memelihara perjalanan bangsanya. Pendidikan Kristen mempersiapkan umat untuk menjalani kehidupannya sebagai murid Kristus yang mengimplikasikan suatu tantangan yang khas dan unik yang harus digumuli bersama (Pramudya, 2001). Melalui PAK, diharapkan kebutuhan spiritual peserta didik tidak sekadar terpenuhi tetapi juga memperoleh pencerahan hidup bahkan mengutamakan pembangunan karakter pada peserta didik sehingga mereka bisa memberikan kontribusi positif dan maksimal bagi masyarakat luas (Sianipar, 2017). Oleh karena itu, penyusunan Kurikulum PAK sedapat mungkin mampu menolong peserta didik untuk siap dan mampu menemukan solusi atas berbagai persoalan (Utomo, 2017). Dengan demikian maka PAK akan memberikan sumbangan berarti bagi pembangunan bangsa (Nuhamara, 2018).

Berdasarkan latar belakang masalah yang dipaparkan di atas, yakni dasar pencarian konsep Pendidikan Agama Kristen yang ideal sebagai alternatif atas masalah sosial dan kemanusiaan yang dihadapi peserta didik, maka penulis merasa perlu untuk menggali dan melakukan penelitian atas konsep Pendidikan Humanis Paulo Freire serta relevansinya dengan Pendidikan Agama Kristen jenjang Sekolah Menengah Atas.

\section{Metode Penelitian}

Penelitian ini merupakan penelitian kualitatif deskriptif dengan pendekatan Library Research (penelitian kepustakaan). Metode pengumpulan data yang dipakai adalah metode dokumenter, yaitu mencari dan mengumpulkan data mengenai variabel penelitian berupa buku-buku karangan Paulo 
Freire dan konsep Pendidikan Agama Kristen. Kemudian untuk analisis data, penelitian ini menggunakan analisis isi (Content Analysis).

\section{Hasil dan Pembahasan}

1. Konsep Pendidikan Humanis Paulo Freire

Paulo Freire (Paulo Freire, 2016) merupakan seorang tokoh pendidikan radikal. Ia menawarkan suatu pendidikan alternatif atas konsep pendidikan yang monoton, searah dan tak dialogis. Pemikiran tersebut lahir dari pergumulan selama bekerja di tengah-tengah masyarakat feodal yang hirarkis (Sudirman, 2019). Baginya pendidikan seperti itu hanya menempatkan peserta didik sebagai objek pasif yang hanya dituntut untuk menerima pengetahuan yang diberikan orang lain kepadanya. Proses pembelajaran terpusat pada pendidik sebagai satu-satunya orang yang dianggap berpengetahuan sehingga cenderung searah yang berakibat hilangnya kreatifitas peserta didik. Ia menyebutnya sebagai "Pendidikan Gaya Bank", dimana peserta didik digambarkan mirip ‘tabung kosong' yang selayaknya diisi dengan beragam pengetahuan hingga penuh.

Atas dasar tersebut, ia kemudian menawarkan konsep pendidikan yang sangat berbeda secara substansi. Paradigma pendidikan yang ia tawarkan menempatkan peserta didik sebagai subjek aktif. Berikut beberapa konsep penting Pendidikan Humanis yang merupakan landasan teoritis sekaligus praktis yang ia konsepsikan melalui karya-karyanya.

\section{a. Konsep Manusia}

Manusia merupakan makhluk unik dengan segala ciri khas yang dimilikinya sebagai pembeda dengan makhluk lainnya. Bagi Freire (Paulo Freire, 2016), manusia secara ontologis merupakan subjek aktif yang bertindak terhadap dunia sekaligus mampu mengubah dunia tersebut. Dunia yang merupakan bagian luar manusia adalah sebuah tantangan untuk mengaktualisasikan diri, mengembangkan bakat minat yang dimilikinya guna menciptakan sebuah hal baru yang bermanfaat bagi dirinya dan juga manusia lainnya. Manusia sebagai makhluk yang hidup berdampingan dengan alam sejatinya menghadapi dunia sebagai realitas objektif. Manusia dan dunia saling berinteraksi sehingga manusia diperhadapkan dengan tantangan alam yang menuntut manusia untuk kritis dan secara sadar menanggapi tantangan tersebut dengan reaksi yang dianggap paling rasional. Keputusan tersebut diambil berdasarkan refleksi dengan mengumpulkan data-data objektif menyangkut alam yang membatasinya.

Untuk dapat bertahan hidup maka manusia perlu meminimalisir ketergantungan sepenuhnya dengan alam. Manusia memanfaatkan potensi yang dimiliki untuk memberikan reaksi berdasarkan refleksi terhadap alam. Untuk itu, Freire (Paulo Freire, 2001) membedakan antara adaptasi dan integrasi dalam menyikapi alam sebagai tempat manusia melangsungkan kehidupan. Adaptasi merupakan bentuk pertahanan terhadap alam dengan menyesuaikan diri dengan realitas. Sedangkan integrasi merupakan kemampuan melangsungkan hidup dengan mengubah realitas berdasarkan kondisi dan kebutuhannya. Dengan begitu, manusia dapat menentukan pilihan yang paling rasional dan masuk akan untuk diterapkan dalam kehidupannya.

Freire juga memandang manusia sebagai makhluk yang dapat menangkap semangat zamannya. Manusia yang bergerak dinamis selalu menciptakan sesuatu yang baru dan dengan kekuatan pemikirannya maka manusia dapat menangkap historisitas atas sesuatu yang terjadi pada masa lampau, masa sekarang dan yang akan datang. Sebagaimana Freire (Paulo Freire, 2001) tegaskan: "Untuk mengatasi dimensi tunggal, manusia mampu menjangkau hari kemarin, mengenai hari ini dan menemukan hari esok. Dan dimensi waktu adalah suatu penemuan yang sangat mendasar dalam sejarah kebudayaan manusia. Manusia berada dalam waktu. Mereka ada di dalam, di luar, mewarisi, melibatkan dan mengubah. Manusia tidak terpenjara dalam "hari ini" yang permanen, melainkan hadir dan menjadi temporal. Manusia hadir dari waktu, menyadari temporalitas, membebaskan diri dari "hari ini", dan 
hubungannya dengan dunia menjadi penuh dengan konsekuensi. Peranan manusia dalam dan dengan dunia bukanlah peran yang pasif."

\section{b. Konsep Pendidikan Pembebasan}

Keprihatinan terhadap masalah humanisasi akan membawa manusia pada pengakuan akan adanya dehumanisasi yang melekat dan makin akut dengan kehidupan manusia. Hal tersebut terlihat dari ketidakadilan dan ketimpangan yang dirasakan oleh manusia yang tersisihkan. Sebagaimana ditegaskan Feire (Paulo Freire, 2016): “Tetapi sepanjang humanisasi ataupun dehumanisasi merupakan pilihan-pilihan yang nyata, maka hanya yang pertama itulah yang merupakan fitrah manusia. Fitrah inilah yang senantiasa diingkari, namun demikian dia justru diakui melalui pengingkaran tersebut. Dia dimungkiri lewat perlakukan tidak adil, pemerasan, penindasan, dan kekejaman kaum penindas; dia diakui oleh adanya kerinduan kaum tertindas akan kebebasan dan keadilan, serta oleh perjuangan mereka untuk menemukan kembali harkat kemanusiaan mereka yang hilang."

Freire (Paulo Freire, 2016) menolak keras sikap fatalisme yang menempatkan manusia pada takdir yang hanya dapat diterima dan mutlak tidak dapat diubah. Untuk itu diperlukan alat yang dapat melihat berbagai permasalahan serta akar penyebabnya. Pendidikan yang memberikan wawasan dan pengetahuan kritis merupakan alat yang terbaik. Dalam hal ini, pendidikan berperan sebagai jembatan membuka gerbang kesadaran kritis. Tidak hanya mencapai kesadaran kritis namun diharapkan melangkah menuju upaya pembebasan yang mengantar peserta didik pada langkah konkret untuk mengubah situasi yang selama ini telah mengekang. Dengan demikian, jalan perjuangan akan ditempuh guna mendapatkan kebebasan demi merengkuh harkat kemanusiaan seutuhnya. Sehingga, pendidikan memainkan peran penting humanisasi dengan bergerak bersama kaum tertindas untuk mengubah realitas penindasan menjadi suatu tatanan yang lebih adil dan lebih manusiawi.

c. Konsep Penyadaran

Bagi Freire (Paulo Freire, 2016), manusia mempunyai kemampuan untuk mengetahui sesuatu karena dianugerahi akan oleh Tuhan. Sehingga ia berkeyakinan tidak ada manusia yang bodoh. Dengan kemampuan untuk berpikir maka manusia dapat memahami dan sadar akan berbagai realitas di sekelilingnya. Manusia menangkap realitas tersebut dalam hubungan kausalitas. Semakin manusia cermat mengamati dan memahami berbagai realitas tersebut maka semakin kritislah ia. Begitu pun sebaliknya, jika manusia tidak dapat memahami realitas tersebut secara rasional maka ia akan cenderung terjebak dalam pemahaman yang bersifat magis dan mistis.

Untuk dapat mencapai tujuan penyadaran kritis dan menyeluruh maka Freire (Paulo Freire, 2001) mengajukan program pendidikan yang menyangkut, konsep antropologis mengenai kebudayaan; yaitu pembedaan antara dunia natural dan dunia kultural, peranan aktif manusia dalam dan bersama dengan realitasnya, kebudayaan sebagai hasil kerja manusia (hasil kegiatan yang terus menerus berkelanjutan dengan mencipta dan mencipta kembali), makna transendental dari hubungan manusiawi, dimensi manusiawi dari kebudayaan; kebudayaan sebagai pencapaian sistematis dalam pengalaman manusia (tidak hanya sebagai tindakan menyimpan informasi, melainkan sebagai tindakan kreatif), demokratisasi kebudayaan, membaca dan menulis sebagai kunci untuk memasuki ruang komunikasi tertulis."

Hal ini dimaksudkan bahwa manusia sebagai subjek aktif perubahan dengan mencipta dan terus mencipta kembali serta hadir dalam sejarah yang terus berlanjut.

\section{d. Konsep Pendidikan Hadap Masalah}

Freire (Paulo Freire, 2016) dengan keras mengkritik pola pendidikan yang menempatkan peserta didik sebagai objek. Ia menyebut pola pendidikan konservatif tersebut sebagai "Pendidikan Gaya Bank". Dalam upaya melakukan kritik terhadap sistem tersebut ia mengemukakan konsep pendidikan yaitu ia sebut "Pendidikan Hadap Masalah". Dalam konsep pendidikan hadap masalah, peserta didik diberikan keleluasaan untuk mencari dan menggali serta menemukan pengetahuan. Peserta didik diajak 
untuk mengamati realitas sekelilingnya dan diberi kebebasan untuk berpikir serta berusaha mencari dan menemukan sebab akibat yang menyangkut realitas dan permasalahannya. Dengan demikian, hal tersebut akan mengantar manusia ke jalur untuk menjadi lebih manusiawi sehingga kemampuan berpikir kritisnya akan mulai terbangun dengan menemukan masalah dan akar masalah tersebut.

e. Konsep Pendidikan Dialogis

Konsep pendidikan hadap masalah telah menjadikan pendidik dan peserta didik sebagai subjek yang memainkan peran yang sama. Keduanya dihadapkan sebagai media dalam membangun pengetahuan dan kesadaran pada realitas. Penerapan teori ekstensi dalam pendidikan merupakan tindakan anti dialogis (Supriyanto, 2013). Tindakan tersebut sangat dikecam oleh Freire. Freire mengemukakan pendidikan hadap masalah sebagai alternatif. Pendidikan hadap masalah menempatkan dialog sebagai sarana interaksi terbuka dalam membangun pengetahuan dan kesadaran. Tetapi, dialog yang dimaksud tidak sekedar kata kosong tanpa makna. Freire memaksudkan bahwa dialog tersebut merupakan suatu totalitas dialektis antara refleksi dan aksi yang melahirkan praksis pembebasan dalam tujuan mengubah dunia yang membelenggu kehidupan manusia.

Bagi Freire, rasa cinta mendalam atas dunia sekaligus terhadap sesama manusia merupakan dasar dari sebuah dialog. Freire (Paulo Freire, 2016) dengan tegas menjelaskan: "Sebagai sebuah bentuk laku keberanian, cinta tidak boleh menjadi sentimental, sebagai sebuah laku kebebasan, dia juga tidak boleh dijadikan alat untuk memanipulasi. Cinta harus melahirkan tindakan-tindakan pembebasan berikutnya; jika tidak dia bukan cinta... Jika saya tidak mencinta dunia - jika saya tidak mencintai kehidupan - jika saya tidak mencintai sesama - saya tidak dapat memasuki dialog."

Dengan dialog maka dimensi perjuangan menuju humanisasi akan terbuka yang tidak dibangun dalam relasi dominasi dengan tujuan untuk menguasai dan juga tidak dibangun berdasarkan hubungan vertikal dan patrimonial.

2. Relevansi Konsep Pendidikan Humanis Paulo Freire dengan Pendidikan Agama Kristen

a. Peran Peserta Didik

Sebagaimana telah dijelaskan di atas, dalam konsep pendidikan Freire menempatkan peserta didik sebagai subjek yang hidup berdampingan dengan alam dan menghadapi dunia sebagai realitas objektif. Maka dalam hubungannya dengan Pendidikan Agama Kristen (PAK), PAK (Kementerian Pendidikan dan Kebudayaan, 2014) menghendaki peserta didik yang dapat memahami kasih Allah Tritunggal di dalam Yesus Kristus dan mengasihi Allah dan sesama serta mampu menghayati imannya secara bertanggung jawab dan berakhlak mulia dalam masyarakat majemuk. Hal ini dapat juga dilihat dari Kompetensi Dasar yang hendak dicapai Kurikulum 2013 (Kementerian Pendidikan dan Kebudayaan, 2014), yakni memotivasi peserta didik untuk: (1) Mengembangkan diri sebagai pribadi Kristiani yang tangguh, yang mampu memahami siapa dirinya di hadapan Allah Tritunggal, mengenali potensi diri serta mampu mengembangkan citra diri secara positif; (2) Mampu mengekspresikan kasih yang tulus kepada Tuhan Allah, Pencipta, Penebus dan Pembaharu dengan berbagai cara dan kesempatan; (3) Peduli dan peka merespon kebutuhan sesama dan lingkungan berdasarkan iman yang diyakininya; (4) Tidak bersikap fanatik sempit, sebaliknya dengan kasih dan kebenaran membangun solidaritas dan toleransi dalam pergaulan sehari-hari tanpa kehilangan identitas diri sebagai murid Kristus; (5) Memiliki kesadaran dan proaktif dalam turut serta mewujudkan demokrasi dan HAM di Indonesia; (6) Memiliki kesadaran untuk turut serta memelihara serta menjaga kelestarian alam ciptaan Allah sebagai ketaatan kepada-Nya; (7) Memiliki kesadaran akan keadilan dan kesetaraan jender serta mewujudkannya dengan sikap jujur dan hormat dalam kehidupan; (8) Memiliki kesadaran dalam mengembangkan kreativitas dalam berpikir, menilai, bersikap dan bertindak; (9) Tidak kehilangan ciri khas sebagai anak-anak dan remaja Kristen Indonesia ketika diperhadapkan dengan berbagai tawaran nilai-nilai kehidupan yang bertentangan dengan iman Kristiani. 
Dalam rangka memberi kemampuan tersebut di atas maka pendekatan yang dilakukan pada pembelajaran PAK adalah pendekatan yang berpusat pada peserta didik (student centered). Namun, hal tersebut tidak maksudkan bahwa guru pasif dan membiarkan proses pembelajaran berlangsung tanpa arahan dan pendampingan. Pendekatan yang berpusat pada peserta didik justru menuntut guru untuk bekerja keras dan mampu menemukan serta memaksimalkan seluruh potensi peserta didik secara kreatif. Kreatifitas guru akan memungkinkan peserta didik aktif, berani menyatakan pendapat, berargumen dan kemudian mampu memberikan solusi sesuai dengan potensi yang dimiliki (Pasaribu, 2019). Dengan demikian, pendekatan pembelajaran PAK bersifat student centered, yang memanusiakan manusia dan demokratis serta menghargai peserta didik sebagai subyek dalam pembelajaran, menghargai keanekaragaman peserta didik, memberi tempat bagi peran Roh Kudus. Maka dalam proses seperti ini, kebutuhan peserta didik merupakan kebutuhan utama yang harus terakomodir dalam proses pembelajaran. Proses pembelajaran PAK adalah proses pembelajaran yang mengupayakan peserta didik mengalami pembelajaran melalui aktivitas-aktivitas kreatif yang difasilitasi oleh guru.

\section{b. Kesadaran Individu dan Masyarakat}

Bagi Freire, keprihatinan terhadap masalah humanisasi cepat atau lambat akan membawa pada pengakuan akan adanya masalah dehumanisasi yang kian melekat erat dan makin akut dalam kehidupan manusia. Maka dari itu, Freire senantiasa menyerukan teriakan optimis untuk merubahnya. Di sinilah letak peran pentingnya pendidikan sebagai jembatan untuk membuka gerbang kesadaran kritis dalam menganalisis segala sesuatu yang menyangkut permasalahan dalam kehidupan di sekitar manusia, mulai dari realitas kemiskinan, pengangguran, keterbelakangan hingga ketimpangan penguasaan kekayaan yang ada.

Maka dalam hubungannya dengan Pendidikan Agama Kristen (PAK), PAK menghendaki peserta didik mampu menghayati imannya secara bertanggung jawab dan berakhlak mulia dalam masyarakat majemuk. Untuk itu maka model pembelajaran PAK yang dipakai adalah model paradigma pedagogi reflektif. Pendekatan ini meliputi tiga unsur utama sebagai satu kesatuan dalam pembelajaran yaitu pengalaman, refleksi dan aksi (Kementerian Pendidikan dan Kebudayaan, 2014). (1) Menggali pengalaman faktual maupun aktual yang diangkat dari pengalaman pribadi, kisah, cerita nyata maupun berbagai kisah Alkitab; (2) Melalui refleksi dan permenungan, peserta didik dipandu untuk mencari dan menemukan makna terdalam dari iman dan kepercayaan yang coba ditanamkan melalui pembelajaran PAK, kemudian membentuk kesadaran baru sebagai hasil dari perenungan dan refleksi; (3) Sebagai hasil dari menggali pengalaman dan refleksi, peserta didik melakukan tindakan yang sesuai dengan ajaran imannya. Berbagai metode yang variatif, dinamis, kreatif, partisipatif dan menyenangkan yang bersifat eksploratif dapat dikembangkan dalam pembelajaran PAK.

Untuk memberikan kemampuan analitis dan cara berpikir logis serta kritis maka dalam pembelajaran PAK digunakan model pembelajaran yang tepat dan salah satunya yakni model inkuiri. Model ini lebih menekankan pada keaktifan peserta didik untuk memiliki pengalaman belajar dalam menemukan konsep-konsep materi berdasarkan masalah yang diajukan. (Suhada, 2017). Penekanan kepada peserta didik yang mencari dan menggali serta menjelajahi sendiri, akhirnya menemukan sendiri jawabnya. Di sini peserta didik dilatih untuk menggunakan dan mengembangkan kemampuan berpikirnya dan guru lebih berperan sebagai fasilitator yang kreatif. Guru selalu mengarahkan peserta didik dalam kegiatan pembelajaran (Hutabarat, 2020). Hal ini sangatlah penting karena banyak aspek dan konsep-konsep kepercayaan dan ajaran Kristen yang perlu dipikirkan, dipahami, dan dihayati melalui pengembangan ranah berpikir logis dan kritis. Model pembelajaran ini dapat diterapkan terutama ketika membahas berbagai persoalan yang dihadapi pada masa kini menyangkut keadilan, kesetaraan, demokrasi dan HAM. Sehingga melalui pembelajaran PAK maka peserta didik memiliki kesadaran akan realitas sosial yang ada dan ikut terlibat dalam penanggulangannya. 
c. Pendidikan Berbasis Realitas Sosial

Dalam konsep pendidikan, Freire menempatkan realitas sosial sebagai instrumen penting dalam proses pendidikan guna mematangkan nalar kritis manusia menghadapi dunia serta kompleksitas permasalahan di dalamnya. Freire memandang realitas sebagai sesuatu di luar diri manusia dan merupakan sebuah tantangan bagi manusia untuk mengaktualkan diri, mengembangkan bakat minat yang dimiliki untuk menciptakan sesuatu hal baru yang berguna bagi dirinya sekaligus bagi manusia lainnya. Sedangkan dalam Pendidikan Agama Kristen (PAK) dalam proses dan strategi pembelajarannya menempatkan realitas sosial sebagai media pembelajaran peserta didik dalam mengembangkan kreatifitas dan nalar logis serta kritisnya. Bahkan model pembelajaran PAK tidak hanya menggunakan model inkuiri tetapi juga menggunakan model pengembangan lingkungan dan model aksi-refleksi dan aksi baru.

Dalam model pengembangan lingkungan guru perlu mengajarkan bagaimana peserta didik dapat mendesain lingkungan agar tujuan yang baik dapat diterapkan dan dicapai. Misalnya supaya mampu menerapkan kasih, belajar dengan baik, membuat lingkungan kondusif yang sehat, bersih dan kristiani. Model ini dapat diterapkan dan dilakukan secara sendiri atau mandiri, namun tidak jarang sering harus melibatkan dan menyadarkan orang lain di sekitarnya dalam pengelolaannya. Model aksi-refleksi dan aksi baru. Ini adalah usaha untuk menerapkan iman dalam situasi konkret. Iman dapat dihayati apabila seseorang betul-betul telah menerapkan dan melakukan apa yang diimani. Untuk model ini perlu ditentukan masalahnya lebih dahulu, misalnya masalah pribadi/personal, masalah bersama, atau masalah lingkungan hidup. Selanjutnya secara berturut-turut perlu konsisten diikuti tahapan sebagai berikut: (1) pengungkapan data atau fakta yang diketahui, (2) analisis data, bisa dilakukan dengan perspektif personal, sosial, budaya, agama, ekonomi, ideologi, dll., (3) mencari dan menemukan pengalaman kristiani yang pernah dialami berhubungan dengan masalah yang dibahas, misalnya dari pengalaman umat Kristen selama ini, dari kisah Perjanjian Lama, Perjanjian Baru, etika Kristen, sejarah gereja, dll. (4) merumuskan masalah, atau rumusan keprihatinan, (5) rencana aksi baru, yaitu rencana kegiatan nyata untuk memecahkan masalah berdasarkan rumusan masalah atau keprihatinan iman. Di sini kadang-kadang diperlukan kepemimpinan dan manajemen/pengelolaan. (6) pelaksanaan aksi baru. Model aksi-refleksi-aksi baru tersebut sesungguhnya merupakan model sebagaimana suatu siklus atau spiral, yang dapat diulangi dalam tenggang waktu tertentu.

\section{d. Pendidikan Dialogis Menuju Masyarakat Toleran dan Demokratis}

Bagi Freire, dialog merupakan sebuah kebutuhan mendasar bagi manusia untuk mempertegas eksistensinya. Dialog, sebagai unsur penting dalam pendidikan dengan visi pembebasan tidak akan mungkin tercipta tanpa adanya rasa cinta mendalam atas dunia sekaligus terhadap sesama manusia. Bagi Freire, rasa cinta merupakan dasar bagi dialog dan pendidikan dialogis dimaksudkan sebagai langkah awal untuk memperlancar proses demokratisasi kebudayaan.

Pendidikan Agama Kristen (PAK) secara konseptual menghendaki sebuah upaya untuk menciptakan warga negara yang demokratis. Hal ini dipertegas dalam Kompetensi Dasar PAK Kurikulum 2013 yang disusun mengacu pada Kompetensi Inti sesuai dengan Peraturan Menteri Pendidikan dan Kebudayaan Nomor 69 tahun 2013 tentang kerangka dasar dan struktur kurikulum Sekolah Menengah Atas/ Madrasah Aliyah, yakni tidak bersikap fanatik sempit, sebaliknya dengan kasih dan kebenaran membangun solidaritas dan toleransi dalam pergaulan sehari-hari tanpa kehilangan identitas diri sebagai murid Kristus dan memiliki kesadaran dan proaktif dalam turut serta mewujudkan demokrasi dan HAM di Indonesia (Kementerian Pendidikan dan Kebudayaan, 2014).

Dalam menerapkan sekaligus menanamkan nilai-nilai yang berhubungan dengan sikap toleran dan demokratis maka pembahasan isi kurikulum PAK selalu dimulai dari lingkup yang paling kecil, yaitu diri peserta didik sebagai ciptaan Allah. Kemudian akan dibahas keluarga, teman, lingkungan di sekitar peserta didik, masyarakat di lingkungan sekitarnya dan bangsa Indonesia serta dunia secara keseluruhan dengan berbagai dinamika persoalan. 
Selain itu dalam rangka menanamkan nilai-nilai toleransi dan demokratis, proses pembelajaran PAK juga dapat menggunakan model pengembangan kepribadian dan model pelatihan. Model pengembangan kepribadian bertujuan agar peserta didik dapat mengembangkan dirinya sebagai pribadi Kristen ciptaan Tuhan, dan menjadi berkat bagi lingkungan. Pengembangan kepribadian dilakukan dengan memakai obyek atau tokoh lain. Misalnya tokoh Musa, Debora, Maria ibunda Yesus, Bunda Teresa dari Kolkata, dr. J. Leimena. Atau obyek tertentu, misalnya buah semangka, pohon, lilin, lampu. Beberapa tahap perlu dilakukan: (1) memilih tokoh atau obyek tertentu; (2) menganalisis obyek atau tokoh tertentu sesuai keberadaannya; (3) membandingkan perbedaan dan persamaan diri dengan obyek atau tokoh tertentu tersebut; (4) melihat potensi diri dan talenta yang dimiliki oleh pribadi sebagai anugerah Tuhan; (5) merencanakan pengembangkan diri secara konkret agar menjadi pribadi Kristen yang handal, toleran dan menjadi berkat bagi lingkungan. Sedangkan model pelatihan bertujuan melatih peserta didik agar memiliki kemampuan, keterampilan, wawasan baru dengan dasar iman. Misalnya, wawasan tentang kesadaran jender, sadar lingkungan, peduli pada sesama, demokratis, memiliki keterampilan untuk membaca dan menerapkan Alkitab dalam kehidupan, menolong orang lain, menjadi aktivis Kristen, mengenali dan membuat simbol-simbol kristiani secara kreatif.

\section{Kesimpulan}

Konsep pendidikan humanis Paulo Freire merupakan buah pikiran yang hadir atas dinamika masalah yang mendasar dalam kehidupan masyarakat. Konsep pendidikan tersebut merupakan sebuah proses dan hasil dialektika panjang tentang realitas kehidupan. Sejalan dengan itu, dalam menanggapi berbagai realitas sosial yang hadir dalam kehidupan masyarakat Indonesia maka dilakukan berbagai upaya untuk merespon hal tersebut. Di bidang pendidikan, upaya tersebut ditemukan dalam seperangkat pembelajaran yang memuat pengetahuan tentang manusia dan realitasnya serta kompleksitas yang terdapat didalamnya. Seperangkat pembelajaran tersebut yaitu Pendidikan Agama Kristen. Sebagai sebuah konsep yang dirancang untuk mencapai tujuan, PAK dirancang untuk memenuhi tujuan bagi peserta didik di masa sekarang dan akan datang, yang diatur dalam seperangkat acuan yang disebut kurikulum.

Dari kajian di atas, terdapat relevansi antara konsep pendidikan Humanis Paulo Freire dengan PAK, sebagai berikut: 1) penempatan peserta didik sebagai subjek dalam proses pembelajaran, 2) peran dan fungsi pendidikan sebagai sarana guna membangkitkan kesadaran peserta didik, 3) menempatkan realitas sosial sebagai media pembelajaran, 4) penciptaan suasana belajar dialogis yang mengantar peserta didik menjadi individu yang toleran dan demokratis.

\section{Daftar Pustaka}

Hutabarat, D. (2020). Analisis Pelaksanaan Strategi Pembelajaran Inkuiri dalam Meningkatkan Keaktifan Belajar Siswa SMK Negeri 1 Laguboti Kab. Toba Samosir TP. 2019/2020. Areopagus: Jurnal Pendidikan dan Teologi Kristen, 18 (1), 127-134

Idris, M. (2009). Pendidikan Pembebasan. Dinamika Ilmu: Jurnal Pendidikan, 9 (2), 1-13.

Kementerian Pendidikan dan Kebudayaan. (2014). Pedoman Guru Mata Pelajaran Pendidikan Agama Kristen dan Budi Pekerti. Jakarta: Badan Penelitian dan Pengembangan Pusat Kurikulum dan Perbukuan KEMENDIKBUD.

Kristianto, P. E. (2021). Meneropong Pendidikan Kristiani di Era Pascasekularitas. Dunamis: Jurnal Teologi dan Pendidikan Kristiani, 5 (2), 250-260.

Mansour Fakih, (2010). Pendidikan Popular (Membangun Kesadaran Kritis). Yogyakarta: INSIST Press

Nuhamara, D. (2018). Pengutamaan Dimensi Karakter dalam Pendidikan Agama Kristen. Jurnal Jaffray, 16 (1), 93-115. 
Pasaribu, J. A. (2019). Pengaruh Model Pembelajaran Inkuiri oleh Guru Pendidikan Agama Kristen terhadap Kreatifitas Belajar. Areopagus: Jurnal Pendidikan dan Teologi Kristen, 17 (1), 1-10.

Paulo Freire. (2016). Pendidikan Kaum Tertindas. Jakarta: Pustaka LP3ES.

Paulo Freire. (2001). Pendidikan yang Membebaskan. Jakarta: Media Lintas Batas.

Pramudya, Wahyu. (2001). Mengenal Filsafat Pendidikan Paulo Freire: Antara Banking Concept Of Education, Problem Posing Method, dan Pendidikan Kristen di Indonesia. Veritas: Jurnal Teologi dan Pelayanan, 2 (2), 259-270.

Putra, I Komang Ramadi. (2020). Pendidikan Membebaskan Sebagai Upaya Mewujudkan Generasi Emas 2045. Vidya Sambita: Jurnal Penelitian Agama, 6 (1), 73-84.

Sianipar, Desi. (2017). Pendidikan Agama Kristen yang Membebaskan: Suatu Kajian PAK di Indonesia. Shanan: Jurnal Pendidikan Agama Kristen, 1 (1), 136-157.

Sudirman, P. (2019). Pedagogi Kritis, Sejarah, Perkembangan dan Pemikiran. Jurnal Pendidikan Dasar dan Keguruan, 4 (2), 63-72.

Suhada, H. (2017). Model Pembelajaran Inquiry dan Kemampuan Berpikir Kritis terhadap Keterampilan Proses Sains Siswa Kelas V Pada Mata Pelajaran IPA. JPD: Jurnal Pendidikan Dasar, 8 (2), 13-24

Suharyanto, A. (2015). Pendidikan dan Proses Pembudayaan dalam Keluarga. JUPIIS: Jurnal Pendidikan Ilmu-ilmu Sosial, 7 (2), 162-165

Supriyanto. (2013). Paulo Freire: Biografi Sosial Intelektual Modernisme Pendidikan. Jurnal Al-Ta'dib, 6 (2), 99-115.

Syaikhudin, A. (2012). Konsep Pemikiran Pendidikan Menurut Paulo Freire dan Ki Hajar Dewantoro. Cendekia: Jurnal Kependidikan dan Kemasyarakatan, 10 (1), 79-92.

Telaumbanua, A.H.N. (2020). Peran Guru Pendidikan Agama Kristen dalam Pembentukan Karakter Siswa di Era Industri 4.0. Institutio: Jurnal Pendidikan Agama Kristen, 6 (2), 45-62.

Umiarso \& Zamroni, 2011. Pendidikan Pembebasan dalam Perspektif Barat dan Timur. Yogyakarta: Ar-Ruz Media.

Utomo, B. S. (2017). Revolusi Guru Pendidikan Agama Kristen dalam Mentransformasi Kehidupan Siswa. Dunamis: Jurnal Teologi dan Pendidikan Kristiani, 1 (2), 1-15.

Wowor, J. P. (2021). Partisipasi Pendidikan Kristiani di Ruang Publik dalam Menunjang Deradikalisasi. Kurios: Jurnal Teologi dan Pendidikan Agama Kristen, 7 (1), 108-122. 